\section{Inheritance of Resistance to Crown Rot Caused by Phytophthora capsici in Cucurbita}

\author{
Les D. Padley, Jr., and Eileen A. Kabelka ${ }^{1}$
}

University of Florida, Institute of Food and Agricultural Sciences, Horticultural Sciences Department, 1301 Fifield Hall, P.O. Box 110690, Gainesville, FL 32611-0690

\author{
Pamela D. Roberts \\ University of Florida, Institute of Food and Agricultural Sciences, Southwest \\ Florida Research and Education Center, 2686 SR 29 North, Immokalee, \\ FL 34142
}

Additional index words. breeding, Cucurbita lundelliana, Cucurbita okeechobeenesis, cucurbits, squash

\begin{abstract}
The various disease syndromes caused by Phytopthora capsici Leonian can be devastating to squash (Cucurbita spp.) production areas of the United States. In some growing seasons, yield loss has been reported up to $100 \%$. A recently developed University of Florida Cucurbita breeding line, \#394-1-27-12, resistant to the crown rot syndrome of $\boldsymbol{P}$. capsici, was used to determine the inheritance of resistance to this disease. Data from $F_{1}, F_{2}$, and backcross progeny from crosses of a $P$. capsici-susceptible butternut-type winter squash $(C$. moschata) with \#394-1-27-12 indicated that resistance is conferred by three dominant genes. The introgression of $P$. capsici crown rot resistance from \#394-1-27-12 into morphologically diverse domesticates within Cucurbita will aid in the management of this economically important pathogen.
\end{abstract}

The oomycetous pathogen, Phytophthora capsici Leonian, is capable of causing several disease syndromes in cucurbits, including crown rot, foliar blight, and fruit rot (Roberts et al., 2001; Zitter et al., 1996). Crown rot appears at the soil line as a dark brown, water-soaked lesion that quickly collapses the stem causing plant death. Foliar blight appears as rapidly expanding, water-soaked lesions on the leaves that eventually causes dieback of shoot tips, wilting, shoot rot, and plant death. Fruit rot appears as sunken, brown, water-soaked areas that are rapidly covered by white sporangial growth under moist environmental conditions.

The incidence of disease caused by $P$. capsici in cucurbit production areas of the United States has increased with reported yield loss as high as $100 \%$ (Hausbeck and Lamour, 2004; Tian and Babadoost, 2004). Given optimal environmental conditions, an entire cucurbit field may be destroyed by $P$. capsici in a matter of days (Roberts et al., 2001; Zitter et al., 1996). The increased occurrence of $P$. capsici has prompted research for improved fungicide control programs and an interest in breeding cucurbits for resistance to P. capsici (Babadoost, 2000; French-Monar et al., 2005; Hausbeck and Lamour, 2004; Keinath, 2007; McGrath,

Received for publication 12 Sept. 2008. Accepted for publication 1 Nov. 2008.

${ }^{1}$ To whom reprint requests should be addressed; e-mail ekabelka@ufl.edu.
2004; Seebold and Horten, 2003; Stevenson et al., 2000, 2001; Tian and Babadoost, 2004; Waldenmaier, 2004).

Cucurbita are considered to be one of the most morphologically variable genera in the plant kingdom (Robinson and DeckerWalters, 1999; Whitaker and Robinson, 1986). There are 22 wild and five cultivated species of Cucurbita. The cultivated species, grown around the world, include C. pepo, C. moschata, C. maxima, C. argyrosperma (formerly C. mixta), and C. ficifolia. Cucurbita cultivars are categorized as summer or winter squash. Summer squash is eaten immature when tender and seeds are small and soft. Winter squash is generally eaten when rind and seeds are fully mature. Summer squash cultivars belong to $C$. pepo, whereas winter squash cultivars may belong to $C$. pepo, C. maxima, C. moschata, or C. argyrosperma.

A search for sources of resistance within Cucurbita to the various syndromes of $P$. capsici had been performed at the University of Florida and included representatives from C. maxima, C. moschata, C. pepo, and three wild species, C. ecuadorensis, C. lundelliana, and $C$. okeechobeensis (Kabelka et al., 2007). From this screen, resistance to the crown rot syndrome of $P$. capsici was identified in the wild species, $C$. lundelliana, and $C$. okeechobeenesis subsp. okeechobeenesis. This resistance, derived from the two wild Cucurbita species, was introgressed through a series of hybridizations, self-pollinations, and single plant selections into a winter squash (C. moschata) back- ground. One line, designated \#394-1-27-12, was advanced to the $F_{7}$ generation and is homozygous for $P$. capsici crown rot resistance. The objective of this study was to characterize the inheritance of resistance to crown rot caused by $P$. capsici within the Cucurbita breeding line \#394-1-27-12.

\section{Materials and Methods}

Plant material. The Cucurbita breeding line \#394-1-27-12, resistant to crown rot caused by $P$. capsici, was crossed with 'Butterbush' (BB), a butternut-type winter squash (C. moschata) highly susceptible to $P$. capsici. Controlled pollinations were carried out in the greenhouse to generate $\mathrm{F}_{1}(\mathrm{BB} \times$ 394-1-27-12), $F_{2}$, and reciprocal backcross (BC) progenies. The susceptible control used in all studies was 'Butterbush'.

Phytophthora capsici isolates and inoculum preparation. Three highly virulent $P$. capsici mating type A1 isolates (01-1938A, RJM98730, and RJM98-805) collected from squash were obtained from Dr. P. Roberts (University of Florida, Southwest Research and Education Center, Immokalee, FL). Inoculum was prepared using a modified procedure based on Mitchell et al. (1978), Mitchell (1978), and Mitchell and KannwischerMitchell (1992). For each P. capsici isolate, one 5-mm mycelial plug from cornmeal agar was transferred to a $20 \%$ clarified V8 agar plate. After $7 \mathrm{~d}$ of growth at room temperature, 10 5-mmV8 agar mycelial plugs from each plate were placed into a $20 \%$ clarified V8 broth plate to grow for an additional $7 \mathrm{~d}$ in a $28{ }^{\circ} \mathrm{C}$ incubator. The V8 broth was then drained and each plate was washed two times with sterilized, distilled water. Sterilized, distilled water was added to cover mycelial growth in all plates, which were then placed under incandescent lights at 28 to $30{ }^{\circ} \mathrm{C}$ to induce sporangial development. After $24 \mathrm{~h}$, sporangia were chilled at $4{ }^{\circ} \mathrm{C}$ for $45 \mathrm{~min}$ to induce zoospore release. The mycelia from each plate were strained through cheesecloth and a $1-\mathrm{mL}$ encysted zoospore sample was counted using a hemacytometer. A suspension of the three isolates, containing equal portions of each, was prepared at a concentration of $2 \times 10^{4}$ zoospores $/ \mathrm{mL}$.

Experimental design and data analysis. Evaluation of \#394-1-27-12, 'Butterbush', $\mathrm{F}_{1}, \mathrm{~F}_{2}$, and $\mathrm{BC}$ progenies for response to $P$. capsici crown inoculation was performed in greenhouse studies using completely randomized designs. Seed were sown in 15.2-cm azalea plastic pots containing Fafard \#3S potting mix (Fafard Inc., Agawam, MA). Seedlings were watered daily and greenhouse temperatures were maintained between 19 and $34{ }^{\circ} \mathrm{C}$. At the cotyledon stage, each seedling received $2 \mathrm{~g}$ of slow-release fertilizer (14N-14P-14K; Grace Sierra Horticulture Products, Milpitas, CA). The $\mathrm{F}_{2}$ progeny test consisted of 200 individuals plus 10 replicates of both parents. The four BC progeny tests, performed separately, consisted of 100 individuals each of $\mathrm{BB} \times \mathrm{F}_{1}$ and $\mathrm{F}_{1} \times \mathrm{BB}$ plus 10 replicates of both parents 

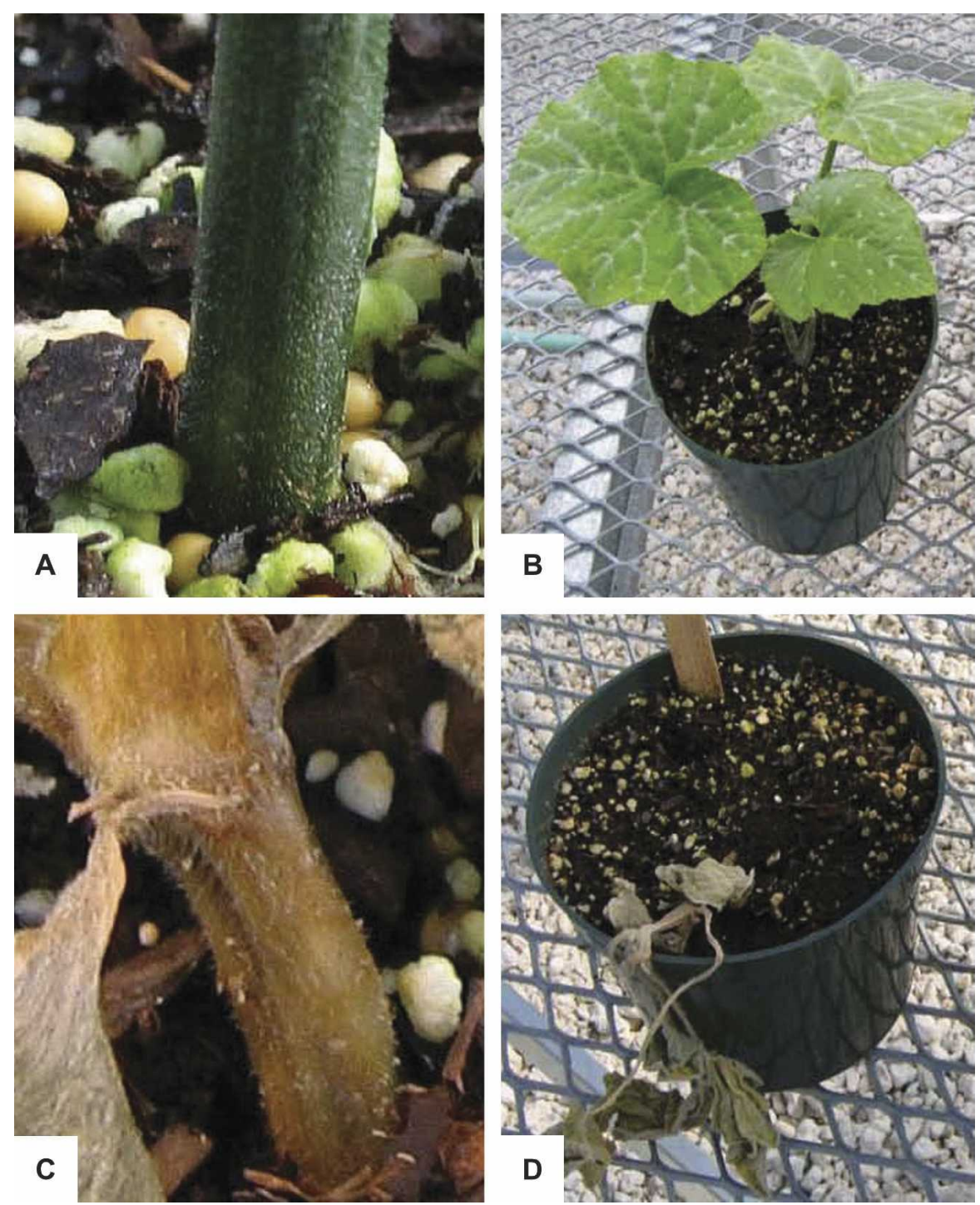

Fig. 1. Response of Cucurbita breeding line \#394-1-27-12 and 'Butterbush' to crown inoculation with a suspension of Phytophthora capsici isolates. (A-B) Breeding line \#394-1-27-12 remains asymptomatic postcrown inoculation. (C) 'Butterbush' develops a tan-brown water-soaked lesion at its crown that rapidly expands causing stem collapse and (D) plant death.

Table 1. Segregation for resistance to Phytophthora capsici crown inoculation in Cucurbita breeding line \#394-1-27-12, 'Butterbush', $\mathrm{F}_{1}, \mathrm{~F}_{2}$, and BC progeny.

\begin{tabular}{|c|c|c|c|c|}
\hline \multirow[b]{2}{*}{ Genotype } & \multicolumn{2}{|c|}{ No. of plants ${ }^{z}$} & \multirow{2}{*}{$\begin{array}{c}\text { Expected } \\
\text { ratio (R:S) }\end{array}$} & \multirow[b]{2}{*}{$\chi^{2}$} \\
\hline & $\mathrm{R}$ & $\mathrm{S}$ & & \\
\hline \#394-1-27-12 & 28 & 0 & - & - \\
\hline Butterbush (BB) & 0 & 38 & - & - \\
\hline $\mathrm{F}_{1}(\mathrm{BB} \times 394-1-27-12)$ & 8 & 0 & - & - \\
\hline $\mathrm{F}_{2}(\mathrm{BB} \times 394-1-27-12)$ & 92 & 108 & $27: 37$ & $1.2 \mathrm{NS}$ \\
\hline $\mathrm{BC}\left(\mathrm{BB} \times \mathrm{F}_{1}\right)$ & 17 & 83 & $1: 7$ & $1.9 \mathrm{NS}$ \\
\hline $\mathrm{BC}\left(\mathrm{F}_{1} \times \mathrm{BB}\right)$ & 10 & 85 & $1: 7$ & $0.3 \mathrm{NS}$ \\
\hline $\mathrm{BC}\left(394-1-27-12 \times \mathrm{F}_{1}\right)$ & 50 & 0 & $1: 0$ & - \\
\hline $\mathrm{BC}\left(\mathrm{F}_{1} \times 394-1-27-12\right)$ & 50 & 0 & $1: 0$ & - \\
\hline
\end{tabular}

${ }^{\mathrm{z}} \mathrm{R}=$ resistant; $\mathrm{S}=$ susceptible.

NS $=\chi^{2}$ value not significant $(P \leq 0.05)$.

and 50 individuals each of 394-1-27-12 $\times \mathrm{F}_{1}$ and $F_{1} \times 394-1-27-12$ plus eight replicates of both parents and the $F_{1}$.

At the second to third true-leaf stage, each seedling was inoculated at its crown with $5 \mathrm{~mL}$ of the $2 \times 10^{4}$ zoospores $/ \mathrm{mL}$ suspension of $P$. capsici. Before inoculation, the potting mix was watered and remained saturated for 24 to $36 \mathrm{~h}$ to optimize the zoospore infection process. Twenty-one days after inoculation, the plants were visually rated based on a scale ranging from 0 to 5 in which $0=$ no symptoms, $1=$ small brown lesion at base of stem, 2 = lesion has progressed up to the cotyledons causing constriction at the base, 3 = plant has partially collapsed with apparent wilting of leaves, $4=$ plant has completely collapsed with severe wilting present, and $5=$ plant death. In all studies, plants scored as 0 were classified as resistant, whereas those scored 1 to 5 were classified as susceptible. To determine the probable number of genes conferring resistance to $P$. capsici crown rot, each segregating population was compared with hypothetical segregation patterns by the $\chi^{2}$ test for goodness of fit (Steel et al., 1997).

\section{Results and Discussion}

The Cucurbita breeding line \#394-1-2712 exhibited no symptoms of crown rot caused by $P$. capsici under the conditions of this study (Fig. 1; Table 1). Five days postinoculation, all individual plants of the susceptible cultivar Butterbush developed tan-brown water-soaked lesions at their crown that rapidly expanded and caused stem collapse and plant death. The $F_{1}$ progeny of the cross between 'Butterbush' and \#3941-27-12 reacted similarly to that of the resistant parent, \#394-1-27-12, remaining asymptomatic. The $\mathrm{F}_{2}$ progeny segregated in a 27:37 [resistant (R):susceptible (S)] ratio, whereas backcrosses to the susceptible parent, 'Butterbush', segregated in a 1:7 (R:S) ratio. Progeny of backcrosses to the parent \#394-1-27-12 were all resistant. Collectively, the segregation ratios support a genetic model in which resistance to the crown rot syndrome caused by $P$. capsici is conferred by three independent dominant genes $\left(\mathrm{R}_{1} \mathrm{R}_{2} \mathrm{R}_{3}\right)$.

Efforts to breed for $P$. capsici crown rot resistance in squash will require the introgression of all three dominant genes conferring resistance from \#394-1-27-12. Plants will be resistant to crown rot only if the three dominant alleles are present in either a homozygous or heterozygous state $\left(\mathrm{R}_{1} \mathrm{R}_{2} \mathrm{R}_{3}\right)$. The identification of molecular markers associated with resistance to $P$. capsici crown rot would facilitate breeding efforts. Using molecular markers, instead of a phenotypic assay, can increase the precision and efficiency of subsequent selection steps applied in plant breeding. Codominant polymerase chain reaction-based molecular markers tightly linked (less than $5 \mathrm{cM}$ ) to $P$. capsici crown rot resistance would provide the most benefit allowing distinction between individuals that are homozygous or heterozygous at each of the three loci required for resistance. Molecular analysis of the segregating progeny developed in this study is currently underway to identify markers linked to the three alleles conferring resistance to $P$. capsici crown rot. Because the genes for resistance to $P$. capsici crown rot within \#394-1-27-12 may be from either $C$. lundelliana or C. okeechobeenesis, or both, molecular analysis may also shed light as to the contributor of this resistance.

In pepper (Capsicum annuum L.), it has been shown that resistance to root rot, stem blight, and foliar blight, caused by $P$. capsici, 
is under different genetic mechanisms (Sy et al., 2005). This is also suggested for potato (Solanum tuberosum L.) in which tuber, vine, and foliage resistance to another Phytophthora species, P. infestans (Mont.) de Bary, is controlled by separate genes (Bonde et al., 1940; Rudorf et al., 1950). Recently, \#394-127-12 has been found to possess resistance to the foliar blight syndrome of $P$. capsici (Kabelka, personal communication). Studies are currently underway to determine if the genetic mechanisms for crown rot and foliar blight resistance within \#394-1-27-12 are the same or are different. This determination is important because either syndrome may result in severe losses in squash production when $P$. capsici is present. Relevant in pepper and potato breeding (Bonde et al., 1940; Rudorf et al., 1950; Sy et al., 2005), if different genes or mechanisms are involved in conferring resistance to crown rot and foliar blight in \#394-1-27-12, successful breeding for resistance to $P$. capsici in squash will require introgression of all resistance genes involved.

Physiological races of $P$. capsici have been identified within the $P$. capsici-C. annuum interaction (Glosier et al., 2008; Oelke et al., 2003). This plays an important role in developing pepper cultivars with resistance to $P$. capsici isolates found in specific growing regions. The resistance in \#394-1-27-12 is currently being tested against $P$. capsici isolates from different regions of the United States and Europe to test for specificity. If physiological races within the $P$. capsici-Cucurbita interaction are identified, it will play an important role in breeding for $P$. capsici resistance within Cucurbita.

Different screening methods have been developed to examine plants for their response to the various disease syndromes caused by $P$. capsici. The greenhouse assay used in this study allowed for precise observations of plant response to crown inoculation and for the determination of inheritance of resistance to crown rot caused by $P$. capsici. This assay provides a standardized test environment and allows for the screening of test material using defined P. capsici inoculum sources. This assay will aide in the introgression of $P$. capsici crown rot resistance from \#394-1-27-12 into the morphologically diverse edible-fruited domesticates within Cucurbita.

\section{Literature Cited}

Babadoost, M. 2000. Outbreak of Phytophthora foliar blight and fruit rot in processing pumpkin field in Illinois. Plant Dis. 84:1345.

Bonde, R., F.J. Stevenson, and C.F. Clark. 1940. Resistance of certain potato varieties and seedling progenies to late blight in the tubers. Phytopathology 30:733-748.

French-Monar, R., P. Roberts, and J. Jones. 2005. Insensitivity of isolates of Phytophthora capsici to mefanoxam in southeast Florida. Phytopathology 95:S31-S32.

Glosier, B.R., E.A. Ogundiwin, G.S. Sidhu, D.R. Sischo, and J.P. Prince. 2008. A differential series of pepper (Capsicum annuum) lines delineates fourteen physiological races of Phytophthora capsici. Euphytica 162:2330.

Hausbeck, M.K. and K.H. Lamour. 2004. Phytophthora capsici on vegetable crops: Research progress and management challenges. Plant Dis. 88:1292-1303.

Kabelka, E.A., L.D. Padley, Jr., P. Roberts, L. Ramos, M. Martinez, and W. Klassen. 2007. Resistance to Phytophthora capsici within winter squash (Cucurbita moschata) derived from a wild Cucurbita species. HortScience 42:1014.

Keinath, A.P. 2007. Sensitivity of isolates of Phytophthora capsici from South Carolina to mefenoxam, dimethomorph, zoxamide and cymoxanil. Plant Dis. 91:743-748.

McGrath, M.T. 2004. Evaluation of fungicides for managing Phytophthora blight of squash, 2003. Fungicide Nematicide Tests 59:V054. 7 Jan. 2008. <http://www.plantmanagementnetwork. $\mathrm{org} / \mathrm{pub} /$ trial/fntests/reports/2004/V054.pdf $>$.

Mitchell, D.J. 1978. Relationships of inoculum levels of several soilborne species of Phytophthora and Phythium to infection of several hosts. Phytopathology 68:1754-1759.

Mitchell, D.J. and M.E. Kannwischer-Mitchell. 1992. Phytophthora, p. 31-38. In: Singleton, L.L., J.D. Mihail, and C.M. Ruch (eds.). Methods for research on soilborne phytopathogenic fungi. American Phytopathological Society, St. Paul, MN.

Mitchell, D.J., M.E. Kannwischer, and E.S. Moore. 1978. Relationship of numbers of Phytophthora cryptogea zoospores to infection and mortality of watercress. Phytopathology 68:1446-1448.

Oelke, L.M., P.W. Bosland, and R. Steiner. 2003. Differentiation of race specific resistance to phytophthora root rot and foliar blight in Capsicum annuum. J. Amer. Soc. Hort. Sci. 128:213-218.

Roberts, P.D., R.J. McGovern, T.A. Kucharek, and D.J. Mitchell. 2001. Vegetable diseases caused by Phytophthora capsici in Florida. 10 Dec. 2007. UF/IFAS EDIS publication. <http:// edis.ufl.edu $>$.

Robinson, R.W. and D.S. Decker-Walters. 1999. Cucurbits. CAB Intl., New York, NY.

Rudorf, W., P. Schaper, H. Ross, M. Baerecke, and M. Torka. 1950. The breeding of resistant varieties of potatoes. Amer. Potato J. 27:222235.

Seebold, K.W. and T.B. Horten. 2003. Evaluation of fungicides for control of Phytophthora crown and fruit rot of summer squash, 2002. Fungicide Nematicide Tests. 58:V098. 9. Jan. 2008. <http://www.plantmanagementnetwork. org/pub/trial/fntests/reports/2003/V098.pdfs

Steel, R.G.D., J.H. Torrie, and D.A. Dickey. 1997. Principles and procedures of statistics: A biometrical approach. McGraw-Hill Companies, Inc., New York, NY.

Stevenson, W.R., R.V. James, and R.E. Rand. 2000. Evaluation of selected fungicides to control Phytophthora blight and fruit rot of cucumber. Fungicide Nematacide Tests. 55:163. 9 Jan. 2008. <http://www.plantmanagementnetwork. org/pub/trial/fntests/reports/2001/V16.pdfs.

Stevenson, W.R., R.V. James, and R.E. Rand. 2001. Evaluation of selected fungicides to control Phytophthora blight and fruit rot of cucumber. Fungicide Nematacide Tests. 56:V16. 7 Jan. 2008. <http://www.plantmanagementnetwork. org/pub/trial/fntests/reports/2001/V16.pdf s.

Sy, O., P.W. Bosland, and R. Steiner. 2005. Inheritance of phytophthora stem blight resistance as compared to phytophthora root rot and phytophthora foliar blight resistance in Capsicum annuиm L. J. Amer. Soc. Hort. Sci. 130: 75-78.

Tian, D. and M. Babadoost. 2004. Host range of Phytopthora capsici from pumpkin and pathogenicity of isolates. Plant Dis. 88:485489.

Waldenmaier, C.M. 2004. Evaluation of fungicides for control of pumpkin diseases, 2003. Fungicide Nematicide Tests, 59:V064. 9 Jan. 2008. $<\mathrm{http}$ ://www.plantmanagementnetwork. org/pub/trial/fntests/reports/2004/V064.pdfs.

Whitaker, T.W. and R.W. Robinson. 1986. Squash breeding, p. 209-242. In: Bassett, M. (ed.). Breeding vegetable crops. AVI Publishing Co., Inc., Westport, CT.

Zitter, T.A., D.L. Hopkins, and C.E. Thomas (eds.). 1996. Compendium of cucurbit diseases. APS Press, St. Paul, MN. 